\title{
Melvin Pollner and Ethnomethodology
}

\author{
Robert M. Emerson • James A. Holstein
}

Published online: 22 September 2011

(C) Springer Science + Business Media, LLC 2011

\section{Editors' Introduction}

When Melvin Pollner passed away in 2007, ethnomethodology lost a pioneering spirit. From the very beginning, ethnomethodologists have been an iconoclastic, fractious lot. Mel, however, embodied an inclusive vision of ethnomethodology, maintaining personal and intellectual relationships that cut across its factions and divisions, and sought common ground with other sociologists. This issue of The American Sociologist commemorates the life and work of Mel Pollner by bringing to light some important, yet unfinished thoughts that had not previously been published, and by allowing some key members of his professional community to reflect on what he has taught us.

Mel was deeply committed to sociology, but most passionately to ethnomethodology. Whereas some have remained maddeningly obscure about what constituted the enterprise, Mel described ethnomethodology plainly, yet eloquently: "It is the study of the practices used to craft whatever participants in particular settings recognize as intelligible, meaningful and real." This meant understanding all social matters - gender, and social class, reality and truth — not as fixed objects or facts, but as meanings people create and sustain in interaction with one another. From this simple foundation, Mel moved in profoundly original and innovation directions. Yet, as his colleague, John Heritage wrote in tribute, Mel could render "almost unthinkable ideas in language that was limpid and lapidary, and yet so imaginative that it was like a shower of fireworks." Those familiar with Mel's writing knew it was of a different, more accessible breed than that of most of his contemporaries.

\footnotetext{
J. A. Holstein $(\bowtie)$

Marquette University, Milwaukee, WI, USA

e-mail: james.holstein@marquette.edu

R. M. Emerson

UCLA, Los Angeles, CA, USA

e-mail: remerson@soc.ucla.edu
} 
Mel was in on the ground floor of ethnomethodology when it arrived on the tumultuous scene of the 1960s. Headed to the graduate sociology program at the University of Wisconsin after graduating from the City University of New York in 1962, Mel read Goffman's Presentation of Self in Everyday Life and immediately changed his plans, deciding instead to study sociology with Goffman at the University of California, Berkeley. Like many of those working with Goffman at the time, Mel became interested in the work of Harold Garfinkel, and went to Los Angeles in the summer of 1965 to study with Garfinkel at UCLA. He returned to Berkeley to complete his MA, where Aaron Cicourel further encouraged the ethnomethodological impulse. When Cicourel left Berkeley for the University of California, Santa Barbara, Mel followed him to UCSB. Here, according to Cicourel, Mel quickly became more of a younger faculty colleague than a graduate student, and his emerging dissertation became legendary.

Mel joined the UCLA Sociology Department in 1968, and immediately became a popular and charismatic lecturer on ethnomethodology, with a devoted following among both graduate and undergraduate students. At one point Mel wrote: "My own entry into the field was conditioned by the times: much hiring, anti-establishment, the next new thing, sudden gain of some academic capital, etc." At UCLA he played a major role in making ethnomethodology an active and effective presence in the Sociology Department. His relations with Garfinkel, while collegial on the surface, reflected recurrent tensions and disappointments at a deeper level. In a personal note, Mel remarked: "Harold Garfinkel hired me and defended me; but viewed me as a spy, or, more charitably, as competitor." Mel played important roles in the Department's hiring of Manny Schegloff, John Heritage and Steve Clayman. He reflected that he had "contributed to the sheltering and nursing" of newly minted $\mathrm{PhD}$ ethnomethodologists facing a tough job market in the 1970 s, working closely with Ike Grusky and his NIMH program on mental health evaluation research to support Renee Anspach, Jim Holstein, Mike Lynch and others as post-doctoral fellows. Eric Livingston and Stacy Burns came to ethnomethodology through his undergraduate courses, and he directed numerous ethnomethodological and interactionist $\mathrm{PhD}$ dissertations. Always committed to undergraduate teaching, Mel developed and taught a long-standing, popular undergraduate course on the sociology of mental illness, and served as Vice Chair of Undergraduate Studies in the Department later in his career.

Pollner's major contributions to ethnomethodology derived from his analyses of how people create and sustain a sense of living in one objective and intersubjectively shared world - in short - how people "do" ordinary reality. Just as Evans-Pritchard had analyzed Azande witchcraft as an internally coherent and impermeable system of beliefs and practices, so Mel treated Western notions of reality as "a cultural system which patterns the actions and utterances of members and is drawn upon by them as a way of ordering their projects and circumstances." In a series of influential articles and in his book, Mundane Reason (1987), he examined the ways in which this reality - the ordinarily unquestioned conviction of "an 'out there,' 'public' or 'objective' world" - is produced and sustained in ordinary interaction.

This work on mundane reasoning is remarkable on several counts. First, Mel turned these issues from airy philosophical speculations to grounded empirical studies, examining the actual uses of mundane reason in an ordinary setting - a 
municipal traffic court. Traffic court provided instance after instance of conflicting claims or accounts about what had "really happened." Second, he shifted the center of gravity for thinking about the constructed nature of reality from marginal comments on the deviant and peripheral to the recurrent everyday interactions of ordinary people and institutional actors. Prior scholarship had treated as pathological or curiosities those who did not consistently recognize one objective real world shared in common. They were viewed as "out-of-contact": schizophrenics, developmental others like Piaget's infants who had not yet learned objectconstancy, culturally alien others like the Azande or the Yaqui (of Carlos Castaneda's fame). In contrast, Mel showed how the very same problems in recognizing and sustaining a sense of an objective reality routinely arose and were handled in ordinary, everyday exchanges in traffic court through the processes of mundane reasoning.

Mel argued that mundane reason's assumption of the objectivity of the world generated everyday puzzles or anomalies on the order of "how come he saw it and you did not?" If there is one real world available to all, how can two people see or experience it differently? But mundane reason also provided ways of resolving these nascent reality disjunctures while preserving the notion of one common real world, notably by "discrediting one version as the product of a faulted or inadequate method of observing the world" (e.g., hallucination, paranoia, bias, blindness, deafness, false consciousness). In an article published with Lynn McDonald-Wikler in 1985, Mel provided a detailed case study of these processes of reality construction by analyzing how a family produced and sustained a version of their five year old daughter as of normal intelligence and verbal competence against clinical diagnoses of profound retardation.

A number of Mel's other ethnomethodological writings were widely known. With Don Zimmerman, he published an early programmatic statement of the ethnomethodological approach, "The Everyday World as a Phenomenon," criticizing existing sociological research for using as "resources" commonsense concepts and assumptions that should rather be treated as "topics" for sociological analysis. His article on constitutive and mundane versions of labeling theory provided a fundamental critique of an important sociological conception of deviance. His 1978 chapter on "explicative transactions" provides his most detailed analysis of the routine operation of traffic court, focusing on defendants' use of earlier cases to plan their own best defense and judges' reflexive use of this practice for their own organizational purposes. And finally, in his 1991 American Sociological Review article "Left of Ethnomethodology," Mel lamented the turn away from radical reflexivity (the appreciation of all sociological and ethnomethodological analyses as themselves socially accomplished), and offered this appreciation of the importance of such reflexivity for ethnomethodology and sociology generally: "Left to its own dynamic, radical reflexivity would unsettle ceaselessly. When deployed as an analytic tool, however, it provides purchase on deep and novel levels of practice. Though it is pointless, groundless, and subversive, radical reflexivity delivers to epistemologically-settled communities the work through which points are made, grounds established, and versions of reality secured against subversions."

Mel was also a sociologist of unusual breadth. Few knew that Mel had a strong background in survey research from Berkeley, and that he co-authored quantitative 
articles published in Public Opinion Quarterly and Sociological Inquiry (a very Pollnerian tribute to Durkheim written with Jim Holstein), as well as a version of his MA dissertation on prayer, in the Journal of Health and Social Behavior. Bob Emerson worked with him on a series of ethnographic studies of psychiatric emergency teams and the dynamics of researcher/researched relationships. Mel also published articles on humor and narrative practices in Alcoholics Anonymous, and the social construction of stock market bubbles.

As theoretically and philosophically challenging as Mel's work was, it was also marked by a keen sense of humor. Just as his writing demonstrates Mel's sensitivity to alternate interpretations and possibilities and his willingness to imagine "how one could reason otherwise," his wit capitalized on such possibilities. As lofty and dizzying as his inquiries may have been, he always pursued them with a light empirical touch. His humor often launched from surface and literal understandings to identify and play with alternative meanings. As funny as we remember Mel to be, his humor was never loud, sarcastic, hostile, or negative. Rather his sense of humor mined everyday talk, spontaneously and playfully picking up hidden ironies, pinpointing unappreciated implications. This sense of humor infused his intellectual work. There may be no funnier, and yet more pointed, introduction to a paper in the American Sociological Review than the first paragraph in Mel's article, "Left of Ethnomethodology." Here Mel began with the metaphor of ethnomethodology "settling down in the suburbs of sociology." Then, after briefly citing several signs of professional acceptance, he added: But few in the discipline "want their children to marry an ethnomethodologist, much less to be one - and they rarely hire one."

Mel Pollner left much unfinished. It was his style to labor and anguish over his writings long after others might be satisfied. For the last five years of his life, Mel was trying to come to grips with where ethnomethodology had gone and where it was headed. As he wrote in a personal note: "Perhaps I encountered ethnomethodology in a transient phase just before it rounded the corner to a destination envisioned before hand. But to me, it looked like the bus was headed downtown. Or perhaps I was ecstatic about Wittgenstein's Tractatus, meanwhile he was writing Investigations."

Mel particularly immersed himself in Harold Garfinkel's Ethnomethodology's Program (2002), pouring through its pages, trying to figure out what Garfinkel was saying and where he was going with what Mel saw as a distinctly different version of ethnomethodology in contrast to Garfinkel's (and other's) earlier work. In trying for several years to come to terms with Ethnomethodology's Program, Mel constantly wrote notes and reflections, ruminating about the nature of the changes, whether indeed there were changes, how to read Garfinkel given the obscurities and ambivalences of his writing, what kinds of intellectual enterprises ethnomethodology were involved, and in what direction - if any - ethnomethodology could be or should be moving. Mel pulled together portions of these ruminations into initial forms of two of the articles included in this journal issue - "the End(s) of Ethnomethodology" and "Ethnomethodology from/as/to Business"- - but he had not yet been able to come up with ways of tying together the diverse strands of these writings into a single, sustained examination of Ethnomethodology's Program. Indeed, this may be an impossible task, and we don't attempt it here. Rather, in the third manuscript published here- "Reflections on Garfinkel and Ethnomethodology's Program"-we 
have selected what we considered to be particularly insightful and provocative bits and pieces of Mel's materials and have organized them in a loose fashion into a series of "reflections" focused mainly on Garfinkel and Ethnomethodology's Program. We have take a small measure of editorial license in polishing some of the unfinished text that Mel left us, but the profound intellect and keen insight in these final deliberations is all Mel's.

\section{Selected Works by Melvin Pollner}

Zimmerman, Don H., and Melvin Pollner. 1970. "The Everyday World as a Phenomenon." Pp. 80-103 in Understanding Everyday Life: Towards a Reconstruction of Sociological Knowledge, edited by J. D. Douglas. London: Routledge \& Kegan Paul.

Pollner, Melvin. 1974. "Sociological and Common Sense Models of the Labeling Process.” Pp. 27-40 in Ethnomethodology: Selected Readings, edited by R. Turner. Harmondsworth: Penguin.

Pollner, Melvin. 1974. "Mundane Reasoning." Philosophy of the Social Sciences 4:35-54.

Pollner, Melvin. 1976. "“The Very Coinage of Your Brain': The Anatomy of Reality Disjunctures.” Philosophy of the Social Sciences 5:411-30.

Emerson, Robert M., and Melvin Pollner. 1976. "Dirty Work Designations: Their Features and Consequences in a Psychiatric Setting." Social Problems 23:243-54

Pollner, Melvin. 1978. "Constitutive and Mundane Versions of Labeling Theory." Human Studies 3:285-304.

Emerson, Robert M., and Melvin Pollner. 1978. "The Worst First: Policies and Practices of Psychiatric Case Selection." Sociology of Work and Occupations 5:7596

Pollner, Melvin. 1979. "Explicative Transactions: Making and Managing Meaning in Traffic Court." Pp. 229-55 in Everyday Language: Studies in Ethnomethodology, edited by G. Psathas. New York: Irvington.

Pollner, Melvin, and Robert M. Emerson. 1983. "The Dynamics of Inclusion and Distance in Fieldwork Relations." Pp. 235-52 in Contemporary Field Research: A Collection of Readings, edited by R. M. Emerson. Boston: Little, Brown.

Pollner, Melvin, and L. McDonald-Wikler. 1985. "The Social Construction of Unreality: A Case Study of a Family's Attribution of Competence to a Severely Retarded Child." Family Process 24:241-54

Pollner, Melvin, and James A. Holstein. 1985. "Psychological Well-Being and the Socio-symbolics of Athletic Contests." Sociological Inquiry. 35-291-309.

Pollner, Melvin. 1987. Mundane Reason: Reality in Everyday Life and Sociological Discourse. Cambridge: Cambridge University Press [Italian Edition, Rome: Il Molino; 1995]

Emerson, Robert M., and Melvin Pollner. 1988. "On the Use of Members' Responses to Researchers' Accounts.” Human Organization 47:189-98.

Pollner, Melvin. 1989. "Devine Relations, Social Relations, and Well-Being." Journal of Health and Social Behavior. 30:203-20. 
Pollner, Melvin, and David Goode. 1990. "Ethnomethodology and Personcentered Practices." Person Centered Review 5:203-20.

Pollner, Melvin. 1991. "Left of Ethnomethodology: The Rise and Decline of Radical Reflexivity." American Sociological Review 56:370-80.

Emerson, Robert M., and Melvin Pollner. 1992. "Difference and Dialogue: Members Readings of Ethnographic Texts." Pp. 79-98 in Perspectives on Social Problems: A Research Annual, Vol. 3, edited by G. Miller and J. A. Holstein. Greenwich, CT: JAI Press.

Pollner, Melvin. 1993. "The Reflexivity of Constructionism and the Construction of Reflexivity.” Pp. 199-212 in Reconsidering Social Constructionism: Debates in Social Problems Theory, edited by J. A. Holstein and G. Miller. New York: Aldine de Gruyter.

Pollner, Melvin and Richard Adams. 1994. "The Interpersonal Context of Mental Health Interviews.” Journal of Health and Social Behavior. 35:283-290.

Pollner, Melvin and Jill Stein. 1996. "The Narrative Mapping of Social Worlds: The Voice of Experience in Alcoholics Anonymous." Symbolic Interaction. 19: 203-223.

Pollner, Melvin. 1997. "A World without Words and the World with Words." Human Studies 20:377-81.

Pollner, Melvin and Richard Adams. 1997. "The Effects of Spouse Presence on Appraisals of Emotional Support and Household Strain." Public Opinion Quarterly. 61: 615-626..

Pollner, Melvin. 1998. "The Effects of Interviewer Gender in Mental Health Interviews." Journal of Nervous and Mental Disease. 186:359-373.

Pollner, Melvin and Dana Rosenfeld. 2000. "TheCross-culturing Work of Gay and Lesbian Elderly." Identity through the Life Course in Cross Cultural Perspectives. 5:99-117.

Pollner, Melvin, and Jill Stein. 2000. "Doubled-over in Laughter: Humor and the Construction of Selves in Alcoholics Anonymous.” Pp. 46-63 in Institutional Selves, edited by J. Gubrium and J. A. Holstein. New York: Oxford University Press.

Pollner, Melvin, and Robert M. Emerson. 2001. "Ethnomethodology and Ethnography." Pp. 118-35 in Handbook of Ethnography, edited by P. Atkinson et al. London: Sage.

Emerson, Robert M., and Melvin Pollner. 2001. "Constructing Participant/observation Relations.” Pp. 239-59 in Contemporary Field Research: Perspectives and Formulations, 2nd edition, edited by R. M. Emerson. Prospect Heights, IL: Waveland Press.

Pollner, Melvin. 2002. "Inside the Bubble: Communion, Cognition, and Deep Play at the Intersection of Wall Street and Cyberspace." Pp. 230-46 in Virtual Society? Technology, Cyberbole, Reality, edited by S. Woolgar. Oxford: Oxford University Press.

\section{See also:}

Berard,Tim J. 2002. "Moving Forward by Looking Back: Revisiting Melvin Pollner's 'Constitutive and Mundane Versions of Labeling Theory." Human Studies 25:495-98.

Berard, Tim J. 2003. "Ethnomethodology as Radical Sociology: An Expansive Appreciation of Melvin Pollner's 'Constitutive and Mundane Versions of Labeling Theory."' Human Studies 26:431-48. 